\title{
ORGANIZING EDUCATIONAL ACTIVITIES OF FUTURE LINGUISTS: THE INNOVATIVE EXPERIENCE OF THE UK
}

\section{ОРГАНІЗАЦІЯ НАВЧАЛЬНОЇ ДІЯЛЬНОСТІ МАЙБУТНІХ ФАХІВЦІВ 3 ЛІНГВІСТИКИ: ІННОВАЦІЙНИЙ ДОСВІД УНІВЕРСИТЕТІВ ВЕЛИКОЇ БРИТАНІЇ}

\section{Olga Komochkova ${ }^{1}$ \\ Olena Dorofeyeva ${ }^{2}$}

DOI: https://doi.org/10.30525/978-9934-588-15-0-11

Abstract. Modern challenges of linguistic globalization, strategic guidelines of information space, problems of linguistic ecology and language policy, rapid development of communication technologies in all sectors of society have increased attention to the quality of human communication. The research aims to identify the peculiarities of organizing educational activities of linguists at the UK universities and justify the ways of creative implementation of the UK innovative experience in higher philological education in Ukraine. A set of interrelated research methods was used to accomplish the objectives of the research: analysis and synthesis, induction and deduction, the comparative pedagogical method, the search method, the prognostic method. It is specified that linguistics curricula assess the ability of future linguists to analyze linguistic data, apply different methods of collecting data, as well as their understanding of linguistic concepts, theories, methods, and, accordingly, the relationship between these aspects of linguistic science and the solving of specific linguistic problems. It is found that the forms of organizing educational activities for linguistics students include lectures, seminars, practical classes, laboratory work, workshops, group and individual tutoring. The planning, development

\footnotetext{
${ }^{1} \mathrm{PhD}$ in Pedagogy, Associate Professor of the Department of Foreign Language Practice and Teaching Methodology,

Khmelnytskyi National University, Ukraine

Olena Dorofeyeva2

${ }^{2} \mathrm{PhD}$ in Philology, Associate Professor, Associate Professor of the Department of Foreign Language Practice and Teaching Methodology, Khmelnytskyi National University, Ukraine
} 
and completion of group or individual research projects, micro-group training, asynchronous discussions and virtual learning environment play an important role in educational activities. Innovative teaching methods include verbal (online discussions), visual (multimedia presentations of webpages, web-sites, applications), visual behaviour experiment and practical (web-quests, cyberguides, computer-based projects). The leading role in the informatization of professional training for future linguists is played by the latest software (E-Prime and Matlab) and modern linguistic multimedia laboratories (data processing laboratories, forensic linguistics laboratories, sociolinguistics laboratories, tracking laboratories, psycholinguistic laboratories), which are used for both teaching and independent work of students. The main forms of formative and summative assessment in professional training of specialists in linguistics at British universities are essays, dissertations, seen examinations, unseen examinations, portfolios, creation of online resources (web-sites). The research proves that the establishment of such linguistic laboratories in Ukrainian universities will enhance the level of organization of linguistics students' independent work, encourage them towards personal success and provide optimal conditions for their professional training. The creative combination of traditional and innovative teaching methods and technologies contributes to focusing the educational process to the student's personal success and developing his or her academic autonomy.

\section{1. Ветуп}

Пошук можливих шляхів підвищення ефективності професійної підготовки фахівців-лінгвістів в Україні спонукає до вивчення світового досвіду, зокрема Великої Британії. У сучасному британському науковому дискурсі лінгвістика набула нових дослідницьких векторів, а саме: вивчення суспільної природи мови, закономірностей ії функціювання в різних галузях знань, мовного планування та екології, внутрішньої структури мови, парадигматичної асиметричності терміносистем, мовних трансформацій тощо. На відміну від українських наукових реалій, у Великій Британії існує чітке розмежування предметної специфіки філології та лінгвістики, оскільки вони є самостійними галузями науки, перша вивчає мову і літературу, а друга - досліджує природу, побудову та властивості мов. 
Професійна підготовка фахівців 3 лінгвістики в університетах Великої Британії спрямована на фундаменталізацію та професіоналізацію лінгвістичних знань, універсалізацію практичних умінь, розвиток мовної культури й лінгвістичного мислення, що дають змогу вільно орієнтуватися в сучасних тенденціях розвитку лінгвістики, проводити актуальні лінгвістичні дослідження, розробляти інформаційно-пошукові довідники й тезауруси, проектувати алгоритми автоматичного оброблення текстів, створювати функціональні методики дослідження закономірностей засвоєння мови, аналізувати процеси сприйняття, інтерпретації та планування мовлення, обгрунтовувати суспільну природу мови тощо. В українській освітній практиці розв'язання практичних завдань, що виникають у різноманітних галузях науки й техніки, а також у повсякденному житті людини на основі досліджень мови та мовлення, - завдання професійної підготовки фахівців із прикладної лінгвістики.

Крім того, на сучасному етапі розвитку людства глобалізаційні та інтеграційні процеси зумовлюють фундаментальні зміни в міжнародному освітньому просторі. Популяризація інноваційних технологій видозмінює підходи до професійної підготовки фахівців, що позитивно впливає на розвиток форм, методів і технологій організації навчальної діяльності.

Велика Британія зарекомендувала себе як країна, що застосовує новітні підходи до викладання, навчання й оцінювання, забезпечує можливості сталого розвитку та освіти протягом життя, заохочує студентів розвивати критичне, абстрактне і творче мислення. У всіх освітніх програмах із лінгвістики форми й методи викладання, навчання та оцінювання призначені для досягнення студентами академічного прогресу, тому відображають конкретні цілі професійної підготовки майбутніх фахівців. Розробники освітніх програм чітко узгоджують методи викладання та навчання з очікуваними компетентностями для мотивації майбутніх фахівців з лінгвістики до професійного й особистісного розвитку. Кафедри лінгвістики, які впроваджують освітні програми з лінгвістики, забезпечують своїх студентів повним пакетом документів, де вміщено докладну інформацію про цілі програми, зміст навчальних дисциплін, а також очікувані результати навчання. Крім того, ці освітні програми передбачають урахування особливостей сти- 
лів навчання й навчальної діяльності, поєднують традиційне навчання 3 творчим застосуванням теорії на практиці.

Освітні програми з лінгвістики оцінюють здатність студентів аналізувати лінгвістичні дані, застосовувати різні методи збору таких даних, а також розуміння лінгвістичних концепцій, теорій, методів, взаємозв'язку між цими аспектами лінгвістичної науки та розв'язанням конкретних лінгвістичних проблем. Методи оцінювання узгоджені й систематизовані з окресленими цілями освітніх програм. Також для них характерна інноваційність розроблення методів оцінювання, оскільки освітній стандарт із лінгвістики не обмежує розробників програм окремими методами. Творчий підхід до застосування новітніх педагогічних і технологічних інновацій надасть нові можливості для оцінювання навчальних здібностей студента.

\section{2. Навчальна діяльність майбутніх лінгвістів у Великій Британії: загальна характеристика}

Завдяки науковій міждисциплінарності, освітні програми з лінгвістики передбачають такі основні форми організації навчальної діяльності студентів-лінгвістів (рис. 1):

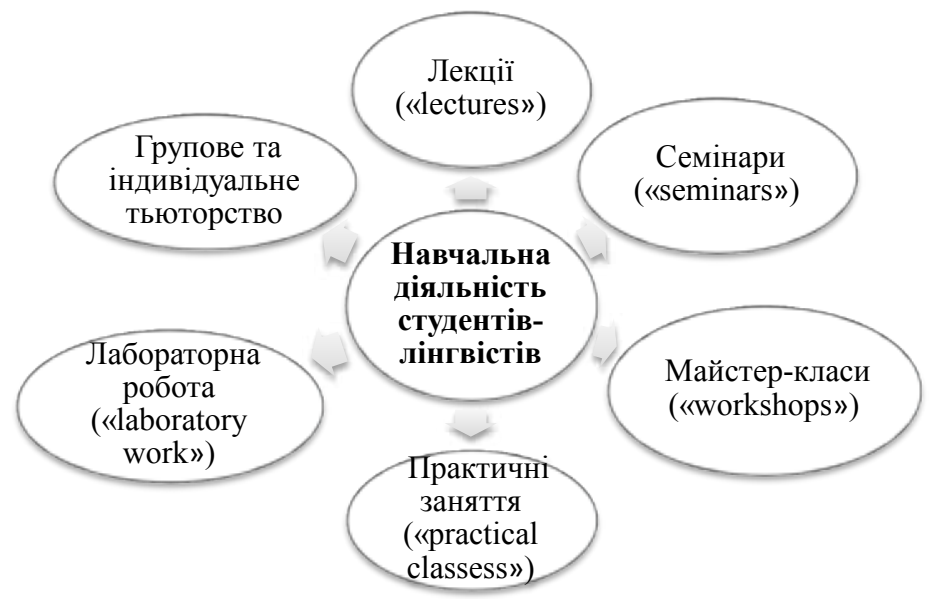

Рис. 1. Форми організації навчальної діяльності студентів-лінгвістів

Джерело: систематизовано автором 
Важливе значення в навчальній діяльності відіграє критичне читання наукової літератури («critical reading of core texts»), усні презентації з використанням мультимедійних засобів («оral presentations, including those using visual presentation software»), планування, розроблення та проведення групових або індивідуальних дослідницьких проектів («planning, design and execution of group or individual research projects»), проблемне навчання із застосуванням вправ на аналіз лінгвістичних даних («problem sets and short exercises involving data analysis»), контрольоване самостійне навчання («supervised independent learning»), використання комп'ютерних технологій навчання («using relevant computer software»), використання віртуального навчального середовища («using virtual learning environments») [18].

Традиційне навчання - передання знань («knowledge transmission») - завжди витлумачували як взаємодію педагога й студента в стаціонарній аудиторії. Однак наразі студенти готові сприймати інформацію, яка надходить із багатьох джерел різноспрямованими потоками, вільно й вибірково. Сферою обміну знаннями стає швидше всесвітня мережа Інтернет, ніж традиційна аудиторія. Інформаційні технології перетворюють власне природу продукування, збереження, інтеграції та передання знань [17].

Інноваційні методи й технології в професійній підготовці фахівців 3 лінгвістики застосовують у традиційних ЗВО (стаціонарна та заочна форми навчання), дистанційно, а також у віртуальних університетах. Як зазначають британські науковці, інформаційні методи навчання повинні не замінювати / дублювати, а доповнювати вже наявні методи навчання $[6 ; 10 ; 12]$.

До інноваційних методів підготовки майбутніх фахівців 3 лінгвістики, зазвичай, зараховують такі (рис. 2) [3].

Веб-квест - це діяльність, заснована на запитах, у ході яких основну інформацію студенти отримують з інтернет-джерел. Веб-квести розроблені так, щоб максимально ефективно використовувати навчальний час. Цього досягають завдяки тому, що акцент поставлений на роботі 3 інформацією, а не на її пошуку. Веб-квести ефективно застосовують у повному спектрі лінгвістичних дисциплін, що вивчають на всіх етапах процесу професійної підготовки фахівців з лінгвістики. Формат моделей веб-квесту дає змогу викладачам допомогти студентам адаптува- 




Рис. 2. Інноваційні методи навчання студентів-лінгвістів Джерело: систематизовано авторами

тися до можливостей Інтернету. Опанувавши високий рівень використання таких моделей, студенти зможуть розробляти власні веб-квести в межах досліджуваних лінгвістичних проблем й обмінюватися ними під час колаборативної діяльності з іншими студентами.

Кібергіди («суberguides») - це спеціально організовані юніти, які засновані на стандартах і передані через мережу. Юніти складаються 3 комплексу інструкцій розробника, призначених як для студентів, так і для викладачів, які працюють зі спеціальною науково-педагогічною літературою. Кожен кібергід розрахований на всіх учасників освітнього процесу. Він містить опис завдання, покрокову інструкцію для досягнення мети й необхідні для отримання результату інтернет-ресурси (відбирає викладач або розробник), способи оцінювання одержаного результату з кількох аспектів (близько шести). Кібергід для викладача містить огляд основних видів діяльності, необхідних для досягнення поставлених цілей, рекомендації розробника й бібліотеку лінків (покликань). Кібергід для студента передбачає наявність директорії діяльності, представленої у форматі, доступному студентам із позиції їхнього віку та здатності сприймати інформацію в письмовій формі. 
Мультимедійна презентаиія - це формат передання інформації, що розрахований на використання тексту, графіки, відео, анімації, звуку. Це, по суті, проектний метод навчання й викладання, під час застосування якого студенти здобувають нові знання, уміння, навички, розробляючи, плануючи і створюючи мультимедійний продукт. Деякі мультимедійні презентації передбачають: 1) створення веб-сторінки або сайту; 2) розроблення гіпермедійних об'єктів; 3) використання мультимедійного додатка для слайд-шоу; 4) знімання фільму, його редагування й монтаж. Складність проектів зростає залежно від розвитку нових мультимедійних форм.

Комп 'ютерні проекти - провідний вид діяльності, що застосовують під час колаборативної роботи. У ході реалізації цієї діяльності відбувається обмін досвідом, переконаннями, даними, стратегіями розв'язання проблем, продуктами, розробленими учасниками самостійно або спільно. До комп'ютерних засобів належить електронна пошта, електронні поштові листи (списки), електронні бюлетені, веб-браузери, дискусійні групи, чати в режимі онлайн, аудіо- й відеоконференції. Онлайнові ресурси охоплюють веб-сайти, інтерактивні середовища, роботизовані пристрої з дистанційним управлінням.

Варто зазначити, що розробники навчальних курсів із лінгвістики описують як переваги, так і недоліки використання Інтернету. Серед переваг називають вільний доступ до інформації, суттєве зменшення навантаження викладачів, можливість застосування різних засобів передання інформації (звукових, візуальних та інших). Крім того, використання університетами навчальних курсів, розроблених іншими ЗВО, сприяє вивільненню часу й коштів для наукових досліджень. До недоліків поширення матеріалів через глобальну комп’ютерну мережу автори зараховують необхідність створення додаткової інфраструктури для розширення доступу до Інтернету та труднощі забезпечення надійного захисту від вірусів. На якості навчання негативно позначається і скорочення контактів між викладачами та студентами $[7 ; 14 ; 15]$.

Нам імпонує досвід Великої Британії в організації навчальної діяльності майбутніх фахівців 3 лінгвістики за допомогою інноваційних комп'ютерних технологій, зокрема віртуального навчального середовища. Як стверджує I. Гініатулін [1], активне впровадження технології віртуального середовища навчання в професійну підготовку фахівців 
3 лінгвістики зумовлене: 1) поширеністю й доступністю електронних баз даних, що містять автентичний матеріал провідних міжнародних семінарів і конференцій із лінгвістики, які можуть бути використані на практичних заняттях та семінарах; 2) полегшенням засвоєння навчального матеріалу за допомогою електронних засобів, що є доцільним, оскільки лінгвістичні теорії, гіпотези та тлумачення важкі для сприйняття, з огляду на на багатовекторність і міждисциплінарність лінгвістики; 3) появою нових можливостей спілкування, що сприятиме соціальній взаємодії між студентами-лінгвістами; 4) видозміною концепції освіти, коли основою стає не інформація, надана викладачем, а самостійна робота студента-лінгвіста [1].

У Великій Британії віртуальне навчальне середовище використовують для організації віртуальних лінгвістичних конференцій. Перевагами таких конференцій варто вважати: 1) високу ефективність навчання студентів-лінгвістів порівняно 3 традиційним навчанням (не всі студенти мають такий вихідний рівень знань, що необхідний для засвоєння інформації, представленої в лекціях, це призводить до труднощів у навчанні; участь у лінгвістичних конференціях дає змогу розпочати навчання за будь-якого початкового рівня знань, вчитися в будь-який час і в будь-якому місці); 2) підвищення ролі студентів у процесі навчання; 3) можливість застосування різноманітних методів навчання; 4) швидкий зворотний зв'язок; 5) можливість багаторазово звертатися до інформації, яка зберігається в електронному форматі; 6) можливість «взаємного навчання» студентів; 7) зміну ролі тьюторів (не контролювати процес навчання, а сприяти йому). Однак варто зазначити, що низка недоліків віртуальних лінгвістичних конференцій гальмує їх масове поширення: 1) емоційно вони бідніші, ніж конференції, які передбачають живе спілкування; 2) існує проблема інформаційного перевантаження, що пов'язане зі складністю лінгвістичних концепцій [1].

Британські науковці доводять, що успіх використання віртуальних лінгвістичних конференцій залежить від: 1) чіткості поставлених завдань; 2) готовності студентів-лінгвістів до опанування комп'ютерних програм, мотивації застосовувати їх у подальшій пошуково-дослідницькій діяльності в межах реалізації лінгвістичних проектів; 3) рівня інтегрованості предметної специфіки таких лінгвістичних 
конференцій до змісту обов'язкових і вибіркових дисциплін; 4) впливу участі в конференції на підсумкову оцінку студента-лінгвіста; 5) наявності програмного забезпечення та постійної допомоги кваліфікованих фахівців-програмістів $[9 ; 13 ; 16]$.

\section{3. Інновації британських університетів \\ в організації навчальної діяльності майбутніх лінгвістів}

Уважаємо за доцільне на прикладі Бангорського університету проілюструвати, яким чином організована навчальна діяльність бакалаврів-лінгвістів (табл. 1) [7].

Отже, освітня програма «Лінгвістика (бакалавр наук)», розроблена Бангорським університетом, спрямована на розвиток компетентності студентів і їхнього критичного розуміння лінгвістичних явищ (структури мови, лінгвістичного різноманіття, концептуальної структури мови тощо). Професійної майстерності майбутніх фахівців 3 лінгвістики досягають через розвиток у них аналітичних і дослідницьких навичок за допомогою методів представлення проектів (у письмовому, усному й онлайн-форматі). Крім того, студенти-лінгвісти вчаться ухвалювати ефективні рішення для розв'язання лінгвістичних проблем, працювати в команді, вкладатися в граничні терміни тощо.

Для вивчення лінгвістики британські університети розробляють надсучасні багатофункційні лінгвомультимедійні лабораторії, призначені не лише для проведення занять викладачем, але й для самостійної роботи. Ці лабораторії відповідають усім сучасним психологічним, гігієнічним та ергономічним вимогам. Зазвичай, вони оснащені персональними комп'ютерами для студентів і викладача, сервером, принтерами, сканерами, телевізором, цифровими камерами, відеокамерами, веб-камерами, інтерактивною дошкою, накладним проектором («digitizer»), програмно-апаратним обладнанням для проведення міжнародних конференцій, цифровими базами даних із файлами матеріалів іспитів і занять, пакетом програмного забезпечення для безперервного контролю студентів, електронними освітніми засобами, засобами інформаційно-довідкової підтримки навчального процесу тощо [22; 23].

Основними компонентами таких лабораторій є: комп’ютер або консоль викладача $з$ програмним забезпеченням для проведення занять; головна гарнітура для викладача і студентів, що блокує зовнішні 


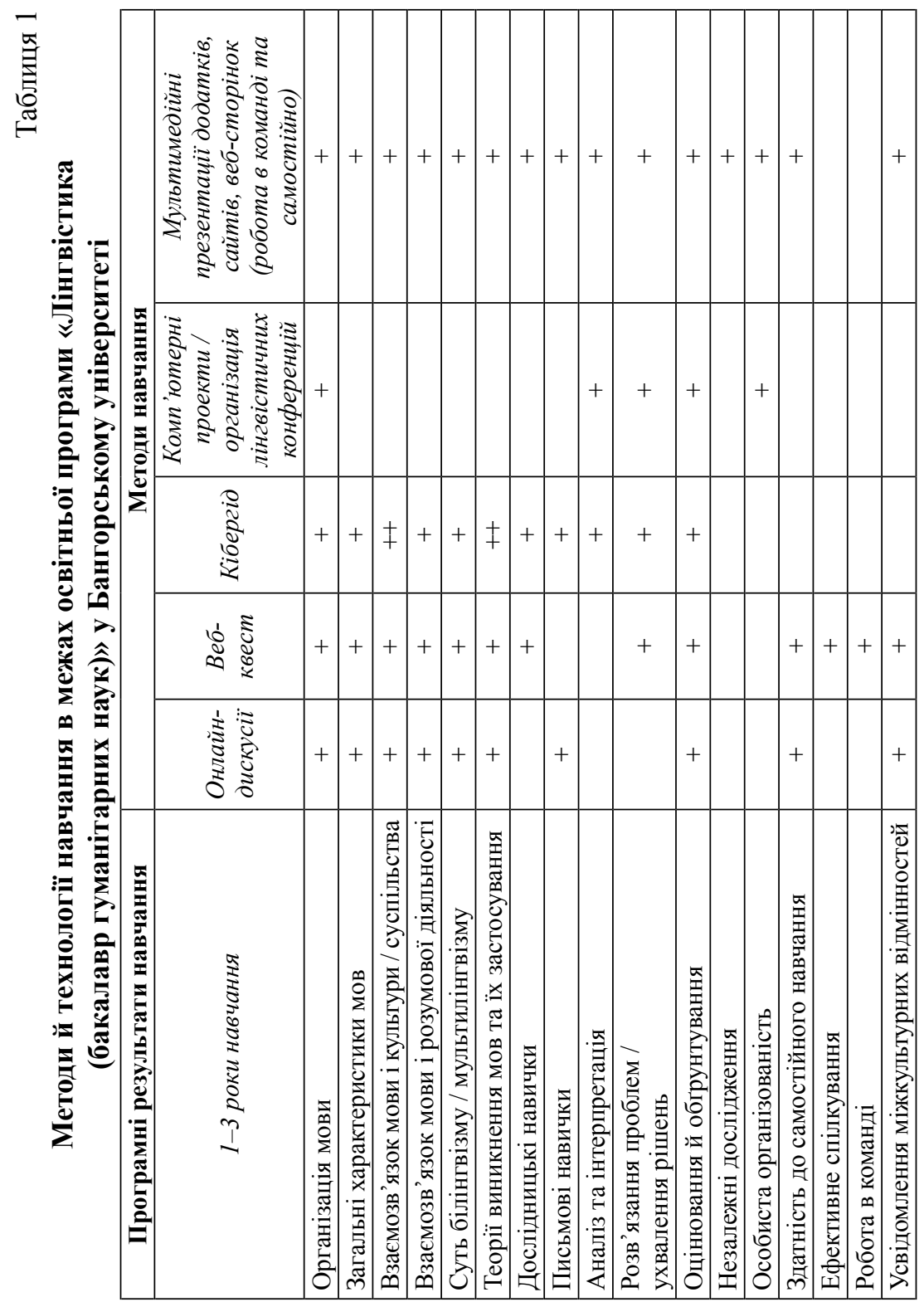


звуки; спеціальні пристрої, які дають змогу маніпулювати цифровими даними (запис, відтворення, прийом-передання, архівування); локальна мережа або окремий кабель; сервер або зовнішній пристрій для зберігання навчальних матеріалів та інших організаційно-методичних матеріалів у цифровому форматі. Функціювання кабінетів побудоване на базі програмних або програмно-апаратних комплексів, що створюють умови для реалізації різних форм інформаційної взаємодії освітнього призначення між усіма учасниками процесу навчання лінгвістики, зокрема засобами IКТ і засобами навчання, що функціюють на базі засобів IКТ. Такі комплекси називають мовними лабораторіями, мультимедійними платформами, мовним програмним забезпеченням тощо.

Варте дослідницької уваги технологічне забезпечення в Йоркському університеті. Студенти-лінгвісти мають змогу розвивати професійні вміння й навички в трьох лабораторіях: лабораторії оброблення даних («data lab»), лабораторії криміналістичної лінгвістики («forensics lab»), лабораторії соціолінгвістики («sociolnguistics»). У лабораторії оброблення даних зібрано величезний обсяг відомостей, які обробляють за допомогою акустичного, корпусного і статистичного аналізу. Крім того, лабораторію використовують для організації зустрічей, конференцій, семінарів, презентацій тощо. У лабораторії криміналістичної лінгвістики студенти, які обрали спеціалізацію «Криміналістична лінгвістика», щотижня відвідують сесії, під час яких аналізують автентичні дані криміналістичної тематики. У лабораторії соціолінгвістики комп'ютери оснащені програмами «E-Prime» i «Matlab», що використовують для проведення візуальних поведінкових експериментів («visual behavioural experiments») [21].

В Есекському університеті працює експериментальна лабораторія «Visual World», яка оснащена новітнім обладнанням, що вможливлює відеореєстрацію інтервалу часу надання відповідей респондентами й рухів їхніх очей, коли їм показують різні відео та зображення. Крім того, існує лабораторія відстежування погляду («еye-tracking lab»), де студенти-лінгвісти відстежують рух очей учасників експерименту, коли вони роблять різні завдання. У психолінгвістичній лабораторії вимірюють часовий інтервал реакцій учасників експерименту на слова, тексти та звуки; у лінгвістичній лабораторії аналізують звуки [20]. 
Дж. Ротері [19] зазначає, що самостійна позааудиторна робота студентів посідає провідне місце в процесі формування професійної компетенції майбутнього фахівця з лінгвістики. Науковець стверджує, що виконання самостійної роботи не лише дає змогу здобути нові знання та відпрацювати отримані вміння, навички, а й має позитивний психологічний вплив на майбутнього фахівця. Під час самостійної роботи студенти-лінгвісти можуть відпочити від «зовнішнього тиску», оскільки перебіг самостійної навчально-пізнавальної діяльності не обмежений у часі та не передбачає конкуренції. Крім того, відповідальність за успішність засвоєння навчального матеріалу, запланованого для самостійного опанування, покладена на майбутнього фахівця. Основними формами організації самостійної роботи майбутніх фахівців з лінгвістики є: критичне читання наукових статей і науково-педагогічної літератури, робота над індивідуальними й груповими проектами, дослідниџька діяльність, підготовка індивідуальних завдань, презентаиій, підготовка до іспитів. Отже, самостійна робота студентів слугує підгрунтям для формування й розвитку особистості, якій притаманні творча індивідуальність, високий рівень знань, загальна та професійна культура, а також постає як основна дидактична умова оптимізації навчального процесу.

У процесі дослідження основних форм організації навчання в британських університетах визначено відсоткове співвідношення аудиторної і самостійної роботи на освітніх програмах із лінгвістики. Від загального обсягу освітньої програми бакалаврів аудиторна робота становить $17 \%$ (перший рік навчання), 16\% (другий рік навчання), $12 \%$ (третій рік навчання); самостійна робота $-83 \%$ (перший рік навчання), $84 \%$ (другий рік навчання), $88 \%$ (третій рік навчання). Організація навчання в магістратурі передбачає два етапи: $15 \%$ - практичний (лекції та семінари), 80\% - теоретичний (дослідницький).

\section{4. Особливості оцінювання навчальної діяльності майбутніх лінгвістів}

У більшості британських університетів академічні досягнення студентів оцінюють щосеместру індивідуально за допомогою різноманітних засобів оцінювання для поетапного визначення якості підготовки майбутніх фахівців. При цьому види атестації й контролю диференціюють на: 
- поточний («continuous assessment») або в деяких університетах - етапний контроль (перевірка й оцінювання знань, умінь і навичок студентів протягом семестру за розділами, окремими дисциплінами, а за необхідності - проведення щоденного контролю); цей вид контролю реалізують у формі лабораторних, курсових робіт, проектів, проведення диспутів, дискусій на семінарських і практичних занять, виконання вправ, рішення задач, обговорення наявних та очікуваних результатів різноманітних видів практик;

- підсумковий іспит («formal examinations») наприкінці кожного навчального року, що передбачає завершення частини або всього курсу; його мета - перевірка не лише знань і вмінь студента 3 дисципліни (курсу), а й навичок самостійної роботи з навчальною та науково-педагогічною літературою;

- підсумкова комплексна атестація (після закінчення університету) $[2 ; 4 ; 5]$.

Основними формами поточного й підсумкового контролю в професійній підготовці фахівців з лінгвістики в британських університетах $\epsilon$ есе (інші види письмових робіт, як-от дисертація), доповіді про індивідуальні й групові проекти, іспити з попереднім оглядом екзаменаційних питань («seen examinations») та іспити без попереднього огляду екзаменаційних питань («иnseen examinations»), що передбачають виконання письмових, усних завдань і «завдань на слухання» («aural assessment»), індивідуальні та групові презентації, короткі вправи ŭ сети інтегральних проблем, що прогнозують застосування аналізу даних, збір та аналіз якісних і кількісних даних, портфоліо, практична робота в лабораторіях, створення онлайн-ресурсів (веб-сайти та вікі), критичне й самооцінювання, слайд-тести, а також завдання, спрямовані на оцінювання конкретних навичок (навички транскрипції, навички інформаційних технологій). В окремих університетах (Нотингемський університет) використовують і такі нетрадиційні форми, як «бібліотечні іспити» («library examinations»), коли студентам дають запитання, відповіді на які вони повинні підготувати протягом 3-4 днів у процесі самостійної роботи в бібліотеці (пошук необхідної інформації за темою, іiі аналіз тощо); аудиторні презентації («сlass presentations»), коли оцінюють уміння студентів організувати, вести групову дискусію та керувати нею. 
Зазвичай, у британських університетах іспити проводять у письмовій формі (для уникнення суб'єктивізму), в окремих випадках, із дозволу Сенату або Ради, допускають усну форму іспиту. Письмовий іспит на отримання спеціального документа за його результатом («paper») триває 3 години. Кандидат складає іспит у зазначений термін і не може відкласти його без дозволу декана факультету. До іспиту не допускають тих студентів, які не відвідували лекції, семінари тощо.

Якщо студент незадовільно склав іспити з одного або більше предметів, то з дозволу декана факультету замість диплома з відзнакою він отримує звичайний диплом бакалавра (Ньюкаслський, Нотингемський університети); можливе повторне складання іспиту, однак не раніше від вересня (до початку нового навчального року - 1 жовтня).

Особа, яка успішно закінчує освітню програму бакалавра, із дозволу декана вповноважена отримати диплом бакалавра з відзнакою. Протягом усього терміну навчання студент має право перейти на освітню програму бакалавра з відзнакою лише один раз (наприклад, у Ньюкаслському університеті).

Система оцінювання академічних досягнень студента містить такі комбінації: «іспит і курсова робота» (Манчестерський університет); «екзамен і практична робота» (Бристольський уніврситет); модулі лише з курсової роботи або з іспитів.

На прикладі Бангорського університету проілюструємо, як організована система оцінювання бакалаврів-лінгвістів у процесі професійної підготовки відповідно до програмних результатів навчання (табл. 2) [7].

Відповідно до таблиці, у Бангорському університеті освітяни застосовують інноваційні та інтерактивні методи оцінювання результатів навчання студентів-лінгвістів, що спонукають майбутніх фахівців до критичного мислення, а також мотивують до розвитку комунікативних, дослідницьких і письмових умінь та навичок.

Отже, серед форм організації навчальної діяльності студентів-лінгвістів домінують лекції, семінари, практичні заняття, лабораторні роботи, майстер-класи, групове та індивідуальне тьюторство. Інноваційні методи навчання мітять словесні (онлайн-дискусіі), наочні (мультимедійні презентації, веб-сторінка, додаток, сайт), візуальний поведінковий метод) і практичні (кібергіди, веб-квести, комп'ютерні проекти). Провідну роль в інформатизації професійної підготовки 
Chapter «Pedagogical sciences»

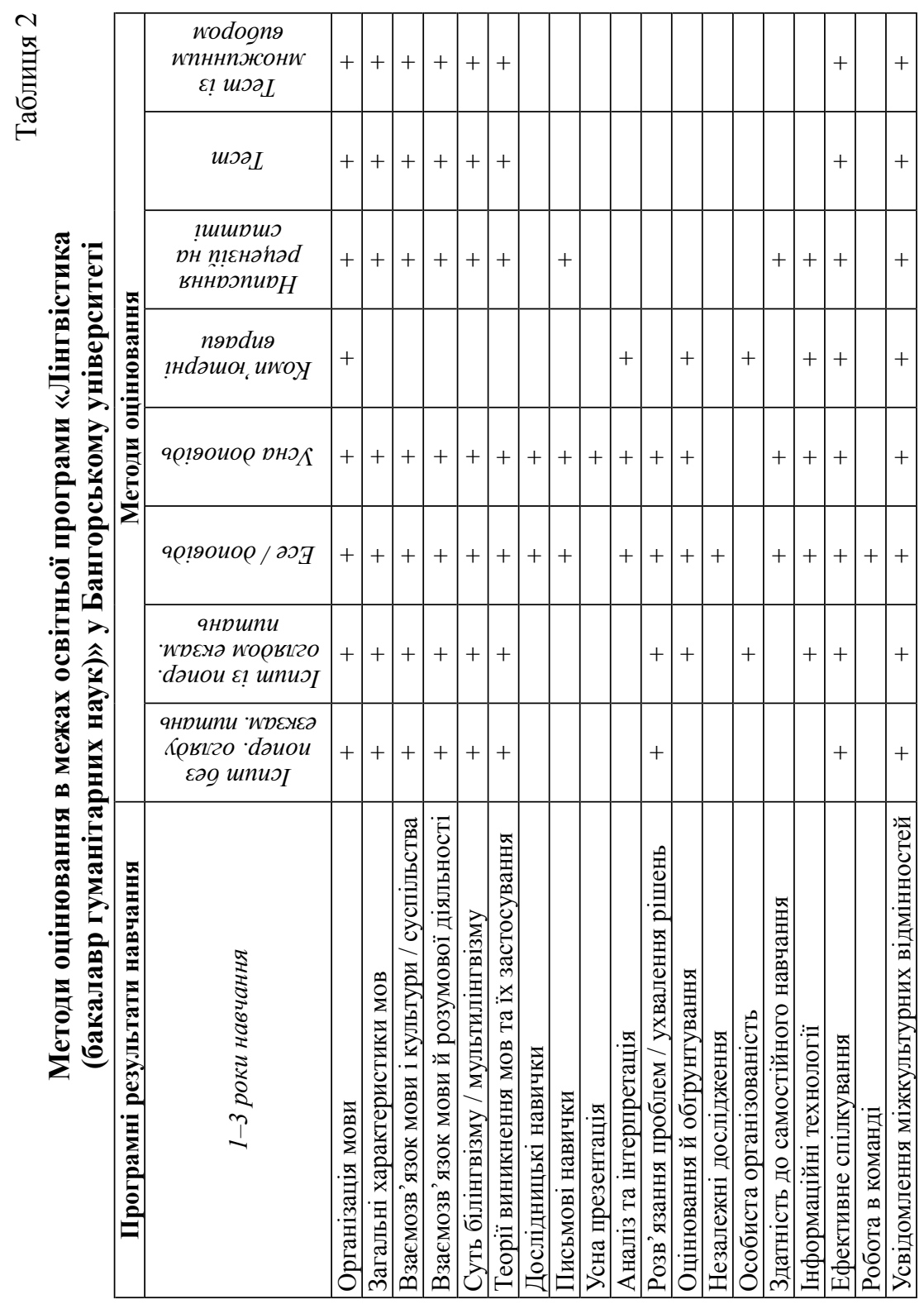


фахівців з лінгвістики відіграє новітнє програмне забезпечення («E-Prime» i «Matlab») та надсучасні лінгвомультимедійні лабораторії (лабораторії криміналістичної лінгвістики, лабораторії соціолінгвістики, лабораторії відстежування погляду, психолінгвістичні лабораторії тощо).

Узагальнені результати досвіду британських університетів в організації навчальної діяльності майбутніх фахівців 3 лінгвістики за допомогою інноваційних методів і технологій спонукають до ретельного вивчення особливостей організації практичної підготовки таких фахівців.

\section{5. Дискусія}

Отже, у британській освітній практиці ефективності професійної підготовки майбутніх фахівців $з$ лінгвістики досягають за допомогою використання інноваційних методів і технологій навчання, оскільки британські освітяни вважають, що професійна підготовка таких фахівців повинна враховувати сучасні виклики лінгвістичної глобалізації, світові тенденції розвитку лінгвістики, міжнародні освітні та професійні стандарти. Варті уваги, зокрема, мультимедійні презентації веб-сторінки, сайту, додатка, комп'ютерні проекти, веб-квести, кібергіди, візуальний поведінковий метод. Ці методи дають студентам змогу максимально ефективно використовувати навчальний час, адаптуватися до можливостей Інтернету, опановувати новітні технології опрацювання мовної інформації; здобувати нові знання, уміння, навички, розробляючи, плануючи та створюючи мультимедійні продукти; обмінюватися досвідом, переконаннями, даними, стратегіями розв'язання проблем, продуктами, створеними учасниками самостійно або спільно; розвивати критичне розуміння лінгвістичних явищ (структури мови, лінгвістичного різноманіття, концептуальної структури мови тощо), аналітичні й дослідницькі навички; ухвалювати ефективні рішення для розв'язання лінгвістичних проблем, працювати в команді, вкладатися в граничні терміни тощо. На нашу думку, імплементація таких позитивних аспектів британського досвіду суттєво б урізноманітнила технологічне забезпечення, застосовуване у вітчизняній теорії і практиці вищої освіти, оскільки перевагу донині надають більш традиційним методам. 
Наголосимо на важливості британських надсучасних лінгвомультимедійних лабораторій (лабораторії оброблення даних, лабораторії криміналістичної лінгвістики, лабораторії соціолінгвістики, лабораторії відстежування погляду, психолінгвістичні лабораторії), які призначені не лише для проведення занять викладачем, але й для самостійної роботи. Заснування лінгвістичних лабораторій такого типу в українських університетах уможливить високий рівень організації самостійної роботи студентів-лінгвістів, зорієнтує їх на особистісний успіх, а також забезпечить оптимальні умови для їхньої професійної підготовки.

\section{6. Висновки}

Таким чином, ефективність та якість професійної підготовки фахівців 3 лінгвістики забезпечується такими інноваційними методами і технологіями навчання, як вебквести, кібергіди, мультимедійні презентації веб-сторінки, комп'ютерні проекти, онлайн-дискусії, візуальний поведінковий експеримент. Провідну роль в інформатизації професійної підготовки фахівців з лінгвістики відіграють надсучасні лінгвомультимедійні лабораторії (лабораторії обробки даних, лабораторії криміналістичної лінгвістики, лабораторії соціолінгвістики, лабораторії відстежування погляду, психолінгвістичні лабораторії). Творче поєднання традиційних та інноваційних методів і технологій навчання сприяє орієнтації процесу навчання на особистий успіх студента та розвиток його навчальної автономії.

Проведене дослідження не вичерпує усіх аспектів зазначеної проблеми. Перспективи подальших наукових пошуків убачаємо в дослідженні особливостей дистанційного навчання майбутніх лінгвістів, вивченні специфіки організації самостійної діяльності, практичної і науково-дослідницької підготовки майбутніх лінгвістів у провідних країнах Свропи та Азії.

\section{Список літератури:}

1. Гиниатуллин И.А. О некоторых аспектах качественной языковой подготовки бакалавров-лингвистов / И.А. Гиниатуллин // Актуальные проблемы германистики, романистики и русистики. - 2014. - Вып. 3. - С. 150-151.

2. Григор'єва Т. Підготовка вчителів-філологів до навчання дорослих у системі неперервної освіти Великої Британії : автореф. дис. на здобуття наук. 
ступеня канд. пед. наук : спец. 13.00.04 «Теорія та методика професійної освіти» / Тетяна Григор'єва. Житомир, 2010. - 20 с.

3. Есенина Н.Е. Информатизация лингвистического образования: опыт Великобритании / Н.Е. Есенина // Интеграция образования. - 2014. Вып. 2. - С. 124-129.

4. Рожак Н.В. Професійна підготовка майбутніх учителів англійської мови в університетах Англії і Шотландії : автореф. дис. на здобуття наук. ступеня канд. пед. наук : спец. 13.00.04 «Теорія та методика професійної освіти» / Наталія Рожак. Тернопіль, 2014. - 19 с.

5. Стрельченко Л. Особливості професійної підготовки вчителя англійської мови у вищих навчальних закладах Великобританії у контексті європейських вимог / Л. Стрельченко // Наукові записки. Серія: педагогічні науки. 2013. - Вип. 121(1). - С. 93-98.

6. Aroyo L. The new challenges for e-learning: the educational semantic web / L. Aroyo, D. Dicheva // Educational Technology \& Society. - 2004. Issue 7 (4). - P. 59-69.

7. Bangor University. Linguistics. Program specification [Electronic Resource]. - Mode of access: http://www.bangor.ac.uk/ar/main/KIS-docs/Final/ Q100.pdf

8. Bangor University. Module QXL-3341. Dissertation [Electronic Resource]. - Mode of access: https://www.bangor.ac.uk/linguistics/undergraduatemodules/QXL-3341

9. Chen C.-M. Personalized intelligent mobile learning system for supporting effective English learning / C.-M. Chen, S.-H. Hsu // Educational Technology \& Society. - 2008. - Issue 11(3). - P. 153-180.

10. Creme P. Why can't we allow students to be more creative? / P. Crème // Teaching in Higher Education. - 2003. - Issue 8(2). - P. 273-277.

11. Demetriadis S. E-lectures for flexible learning: a study on their learning efficiency / S. Demetriadis, A. Pombortsis // Educational Technology \& Society. Issue 10(2). - P. 147-157.

12. Donnelly R. Applied e-learning and teaching in higher education / R. Donnelly, F. McSweeney. - Hershey, PA: Information Science Reference, 2009. $-440 \mathrm{p}$.

13. Hall D. Innovation in English language teaching: a reader / D. Hall, A. Hewings. - London: Routledge, 2001. - 304 p.

14. Holzinger A. Dynamic media in computer science education, content complexity and learning performance: Is less more? / A. Holzinger, M. Kickmeier-Rust, D. Albert // Educational Technology \& Society. - 2008. Issue 11(1). - P. 279-290.

15. Hou H.-T. Analysis of problem-solving-based online asynchronous discussion pattern / H.-T. Hou, K.-E. Chang, Y.-T. Sung // Educational Technology \& Society. - 2008. - Issue 11(1). - P. 17-28.

16. Lee Y. The past, present, and future of research in distance education: results of a content analysis / Y. Lee, M. P. Driscoll, D. W. Nelson // The American Journal of Distance Education. - 2004. - Issue 18(4). - P. 225-241. 
17. Minshall T. What is knowledge transfer? / T. Minshall [Electronic Resource]. - Mode of access: http://www.cam.ac.uk/research/news/what-isknowledge-transfer

18. Quality Assurance Agency. UK Quality Code for Higher Education. Subject Benchmark Statement. Linguistics [Electronic Resource]. - Mode of access: http://www.qaa.ac.uk/en/Publications/Documents/SBS-Linguistics-15.pdf

19. Rothery J. Making changes: developing an educational linguistics / J. Rothery // Literacy in Society. - London: Longman, 1996. - P. 86-123.

20. University of Essex. BAinLinguistics[ElectronicResource].-Modeofaccess: https://www.essex.ac.uk/coursefinder/course details.aspx? course $=\mathrm{ba}++\mathrm{q} 100$

21. University of York. MA in Linguistics [Electronic Resource]. - Mode of access: https://www.york.ac.uk/language/postgraduate/taught/linguistics/

22. Vanderplank R. Déjà vu? A decade of research on language laboratories, television and video in language learning / R. Vanderplank // Language Teaching. 2010. - Issue 43(1). - P. 1-37.

23. Virvou M. Combining software games with education: evaluation of its educational effectiveness / M. Virvou, G. Katsionis, K. Manos // Educational Technology \& Society. - 2005. - Issue 8(2). - P. 54-65.

\section{References:}

1. Giniatullin, I.A. (2014). On some aspects of high-quality language training for Bachelors in Linguistsics. Relevant Issues of German, Romance and Russian Studies, 3, 150-151.

2. Hryhorieva, T. (2010). Training language teachers for adult learning in the UK system of lifelong learning. (Abstract of PhD thesus). Ivan Franko Zhytomyr State University, Zhytomyr.

3. Esenina, N.E. (2013). The informatization of linguistic education: the UK Experience. Integration of Education, 2, 124-129.

4. Rozhak, N.V. (2014). Professional training of English teachers at the universities in England and Scotland. (Abstract of PhD thesis). Volodymyr Hnatiuk Ternopil National Pedagogical University, Ternopil.

5. Strelchenko, L. (2013). The characteristics of English teachers' professional training in higher education institutions in the UK in the context of European requirements. Scientific Notes. Series: Pedagogical Sciences, 121(1), 93-98.

6. Aroyo, L., \& Dicheva, D. (2004). The new challenges for e-learning: the educational semantic web. Educational technology \& society, 7 (4), 59-69.

7. Bangor University (2011). Linguistics. Program specification. Retrieved from http://www.bangor.ac.uk/ar/main/KIS-docs/Final/Q100.pdf

8. Bangor University. (2017). Module QXL-3341. Dissertation. Retrieved from https://www.bangor.ac.uk/linguistics/undergraduate-modules/QXL-3341

9. Chen, C.-M., \& Hsu, S.-H. (2008). Personalized intelligent mobile learning system for supporting effective English learning. Educational technology \& society, 11(3), 153-180.

10. Creme, P. (2003). Why can't we allow students to be more creative? Teaching in higher education, 8(2), 273-277. 
11. Demetriadis, S., \& Pombortsis, A. (2007). E-lectures for flexible learning: a study on their learning efficiency. Educational technology \& society, 10(2), $147-157$.

12. Donnelly, R. \& McSweeney, (2009). Applied e-learning and teaching in higher education. Hershey, PA: Information Science Reference.

13. Hall, D., \& Hewings, A. (2001). Innovation in English language teaching: a reader. London: Routledge.

14. Holzinger, A., Kickmeier-Rust, M., \& Albert, D. (2008). Dynamic media in computer science education, content complexity and learning performance: Is less more? Educational technology \& society, 11(1), 279-290.

15. Hou, H.-T., Chang, K.-E., \& Sung, Y.-T. (2008). Analysis of problemsolving-based online asynchronous discussion pattern. Educational technology \& society, 11(1), 17-28.

16. Lee, Y., Driscoll, M. P., \& Nelson, D. W. (2004). The past, present, and future of research in distance education: results of a content analysis. The American journal of distance education, 18(4), 225-241.

17. Minshall, T. (2009). What is knowledge transfer? Retrieved from: http://www.cam.ac.uk/research/news/what-is-knowledge-transfer

18. Quality Assurance Agency (2015). UK Quality Code for Higher Education. Subject Benchmark Statement. Linguistics. Retrieved from http://www.qaa.ac.uk/ en/Publications/Documents/SBS-Linguistics-15.pdf

19. Rothery, J. (1996). Making changes: developing an educational linguistics. In R. Hasan, \& G. Williams (Eds.), Literacy in society, pp. 86-123. London: Longman.

20. University of Essex (2015). BA in Linguistics. Retrieved from: https://www.essex.ac.uk/coursefinder/course_details.aspx?course=ba $++\mathrm{q} 100$

21. University of York (2016). $M \bar{A}$ in Linguistics. Retrieved from: https://www.york.ac.uk/language/postgraduate/taught/linguistics/

22. Vanderplank, R. (2009). Déjà vu? A decade of research on language laboratories, television and video in language learning. Language Teaching, 43(1), 1-37.

23. Virvou, M., Katsionis, G., \& Manos, K. (2005). Combining software games with education: evaluation of its educational effectiveness. Educational technology \& society, 8(2), 54-65. 